2002

\title{
Melding Civil Rights and Environmentalism: Finding Environmental Justice's Place in Environmental Regulation
}

Tseming Yang

Santa Clara University School of Law, tyang@scu.edu

Follow this and additional works at: http://digitalcommons.law.scu.edu/facpubs

Part of the Law Commons

\section{Automated Citation}

Tseming Yang, Melding Civil Rights and Environmentalism: Finding Environmental Justice's Place in Environmental Regulation, 26 HaRv. ENVTL. L. Rev. 1 (2002),

Available at: http://digitalcommons.law.scu.edu/facpubs/717 


\title{
MELDING CIVIL RIGHTS AND ENVIRONMENTALISM: FINDING ENVIRONMENTAL JUSTICE'S PLACE IN ENVIRONMENTAL REGULATION
}

\author{
Tseming Yang*
}

\section{INTRODUCTION}

In recent years, the environmental justice movement has posed important challenges to the federal environmental regulatory system, as well as to environmentalism itself. But what has distinguished the environmental justice movement's challenge from those advocating property rights or deregulation has been its politically liberal rather than conservative origin. As a movement seeking to bring the civil rights movement's ideals to environmental protection, the environmental justice movement has shown that environmental political liberalism is not necessarily the same as the political liberalism of those concerned with race and social justice. ${ }^{1}$ The rift has been particularly apparent in the charges of environmental racism against environmentalists and regulators and continues to persist in the difficulties that regulators, in particular, have faced in incorporating the ideals of racial and social justice into the environmental regulatory framework. ${ }^{2}$

As an important explanation for these difficulties, scholars have pointed to the lack of political power held by minority communities and the poor as reasons why government regulators have been less responsive to their concerns. ${ }^{3}$ However, reliance on such explanations alone ignores the genuine concern that many environmentalists and regulators have given these issues and their sincere efforts to overcome such inequalities.

- Associate Professor of Law, Vermont Law School. I am grateful to Sheila Foster, Eileen Gauna, Shubha Ghosh, Cynthia Ho, Gil Kujovich, Susan Kuo, and Kenneth Manaster as well as the participants of the 1999 Asian American Legal Scholarship Workshop for their valuable comments and suggestions on earlier drafts of this Article. Thanks go to Lizbeth Brown, Mateo Davis, Albert Huang, Theresa Labriola, and especially Michael O'Brien for legal research.

1 This has been particularly remarkable since some see the environmental movement as being derivative in many respects of the civil rights movement. See, e.g., Richard J. Lazarus, Pursuing "Environmental Justice": The Distributional Effects of Environmental Protection, 87 Nw. U. L. REv. 787, 853-55 (1993) (explaining that the environmental movement adopted many of the predecessor movement's tools, strategies, and rhetorical approaches); Roderick Frazier Nash, The Rights of Nature 199-213 (1989). Cf. David A. Westbrook, Liberal Environmental Jurisprudence, 27 U.C. DAvis L. REv. 619, 693-708 (1994) (seeking to provide a liberalism-based justification for environmental regulation).

${ }^{2}$ See infra notes 20-22 and accompanying text.

${ }^{3}$ See Sheila Foster, Justice from the Ground Up: Distributive Inequities, Grassroots Resistance, and the Transformative Politics of the Environmental Justice Movement, 86 CaL. L. Rev. 775 (1998). 
Even if such efforts have been insufficient, it would be unfair to describe their responses as cynical attempts to provide only sham remedies. More importantly, such explanations ignore the important constraints that the legal and institutional frameworks impose on the actions of regulators.

The differing frameworks within which environmental justice advocates and environmental regulators operate have significantly shaped the goals and ideals that each group pursues and explain much about the challenge that environmental justice has posed to environmental regulation. In a way, the involved groups have had difficulties understanding each other.

While ongoing dialogue between the environmental justice movement and regulators has led to important progress, continuing severe criticism of EPA efforts in regard to environmental justice shows that there still has not been a "meeting of the minds" regarding approaches and values that should form the basis of appropriate regulation. At the same time, the failure to identify and better understand these frameworks has also obscured how both frameworks have non-obvious structural limitations that make addressing the concerns of the environmental justice movement very difficult.

The central argument of this Article is that law and policy in civil rights and environmental protection have been based on drastically different problem paradigms, and that the failure to understand and address these differences has impeded greater progress in the integration of the concerns of the environmental justice movement into the traditional environmental regulatory framework. ${ }^{4}$ Environmental protection relies in large part on a conception of environmental degradation identified by Garrett Hardin in his seminal article Tragedy of the Commons, ${ }^{5}$ as well as by Rachel Carson in her book Silent Spring. ${ }^{6}$ In contrast, civil rights laws and cases have in large part responded to issues of discrimination which

"A "paradigm" in Thomas Kuhn's usage is an accepted model problem which is characteristic of the issues raised in the field. It is thus a pattern or mold to which many other problems within the field can be analogized. See Thomas S. Kunn, The Structure of Scientific Revolutions viii ( $2 \mathrm{~d}$ ed. 1970). I also use the terms ideology and perspective to describe this type of paradigm thinking.

The paradigms have shaped how those working within it understand their field and the central social problem they are to address as well as how they should go about solving it. See, e.g., Eileen Gauna, The Environmental Justice Misfit: Public Participation and the Paradigm Paradox, 17 STAN. ENvTL. L.J. 3 (1998); Zygmunt J.B. Plater, From the Beginning, A Fundamental Shift of Paradigms: A Theory and Short History of Environmental Law, 27 LOY. L.A. L. REv. 981 (1994); Gerald E. Frug, The Ideology of Bureaucracy in American Law, 97 Harv. L. Rev. 1276 (1984). See also Laurence H. Tribe, American CoNSTITUTIONAL LAW (2d ed. 1988) (presenting several models for understanding the various strands of constitutional law). Accordingly, the paradigm is an ideal that models a problem's basic constituents. Here, its usefulness lies in facilitating the elaboration of thinking, premises, and values that characterize problem-solving and decision-making in civil rights and environmental protection.

${ }^{5}$ Garrett Hardin, The Tragedy of the Commons, 162 SCIENCE 1243 (1968).

${ }^{6}$ RaChel Carson, Silent Spring (Fawcett Crest 1964) (1962). 
are implicit in the Supreme Court's opinion in Brown v. Board of Education. $^{7}$

Since environmental justice is a social problem that has implicated the concern of both civil rights and environmental law, it has brought these regulatory paradigms into significant contact and forced their reconciliation. To the extent that these paradigms are consistent with each other, their combination to solve problems within this overlapping area of regulation is unproblematic. However, to the extent that they conflict or are inconsistent, their combination creates tensions that manifest themselves in the real world as disagreements about appropriate regulatory responses or conflicts over what are or are not legitimate problems worthy of regulatory attention.

Understanding how these paradigms conflict or are in harmony will provide not only a better sense of each regulatory system's motivating premises, values, and shortcomings as regulatory solutions, but also will provide insights about the debate and how one might address those tensions. These issues are explored in this Article.

Part II provides a brief overview of the environmental justice movement and the issues of racial and social justice it has raised for environmental regulators.

Part III explains how Garrett Hardin and Rachel Carson have influenced environmentalists' and regulators' thinking about the environmental degradation problems that the regulatory system must address. It also sets out the problems of racism and discrimination that civil rights law and doctrine have sought to remedy and that are implicit in Brown v. Board of Education and its progeny. While at one level these paradigm problems are just stories of how some prominent people and institutions have thought about environmental degradation and racial discrimination, a closer examination tells us much about the underlying values and premises that have come to govern regulatory thinking.

It is important to note here that I am specifically focusing on Brown as a paradigm of the courts' understanding of discrimination and the appropriate solutions to such issues. A tremendous amount of scholarship, in particular critical race scholarship, has indicated the limitations of this understanding. Nevertheless, this description remains important for its representation of how government officials and those not familiar with more recent race scholarship understand discrimination.

7347 U.S. 483 (1954). It is not my claim that these paradigms provide a complete and detailed representation of each and every aspect of the environmental regulatory system or of civil rights law. After all, the construction of ideal-type models is crucial in order to grasp the overall structure of these two areas of public policy without being overwhelmed by their complexities and detail. See Frug, supra note 4, at 1282. However, in spite of the simplification, I do believe that these models provide a fair description of the bulk of environmental and civil rights law. It is an analysis of the overall structures that I am interested in here. 
Part IV addresses the differing values and regulatory premises that the contrasting regulatory paradigms give rise to and the tensions that are created by attempts to superimpose the two systems. The discussion specifically examines the groups-minorities or a larger collective-that each system of regulation is primarily intended to protect, the role of states within the regulatory systems, the role that quantifiable values and incommensurables play in shaping regulation, the issues that expert agencies face in incorporating intangibles into their decision-making processes, and the regulatory limits inherent to each system.

Part $V$ then examines whether these incongruous paradigms can be reconciled. Their differences can be traced to fundamentally divergent regulatory value premises: civil rights law is intended to provide protections against majoritarian pressures, while environmental regulation is largely designed to enhance majoritarian preferences. However, even though the environmental justice movement thus poses a fundamental challenge to the nature and purpose of environmental governance, antidiscrimination and distributional equity concerns retain a legitimate place within the environmental regulatory system. Serious reform efforts to the regulatory process remain necessary and cannot be abandoned in spite of the accompanying political and practical difficulties.

My objective in this Article is not to justify lack of change and failure to make significant progress toward the goal of environmental justice. Rather, it is to emphasize how far away we still are and how much more needs to be done. Simple fixes that do not commit the Environmental Protection Agency ("EPA") and the rest of the federal government to approaching environmental protection in a meaningfully different way will likely provide only the illusion of progress. ${ }^{8}$

\section{The Environmental Justice Movement}

Since the rise of the modern environmental regulatory system in the late 1960s and early 1970s, commentators and activists involved in racial justice issues have voiced specific concerns about the distributional impacts of environmental protection efforts on racial minorities. ${ }^{9}$ They

${ }^{8}$ It should be noted that many of the problems elaborated here apply to the state and local regulation of environmental issues as well. However, they are beyond the scope of this Article.

${ }^{9}$ Scholars have pointed to the discrimination that African Americans and other minorities faced with regard to the provisioning of municipal services during the times of Jim Crow and racial segregation laws as early examples of environmental injustice. See, e.g., Hawkins v. Town of Shaw, Miss., 437 F.2d 1286 (5th Cir. 1971). In posing the discrimination struggle as a fight for equal benefits from government works, they can be seen as the flip-side of the more recent environmental justice complaints regarding unequal treatment in the distribution of undesirable land uses. See Vicki Been, What's Fairness Got to Do With It? Environmental Justice and the Siting of Locally Undesirable Land Uses, 78 CoRNELL L. REv. 1001, 1003 n.9 (1993); Lazarus, supra note 1, at 807, 833. In both instances, residential segregation provided an easy mechanism by which municipalities could not 
pointed out that the nation's then-new environmental regulatory system might allocate resources away from the issues most pressing for racial minorities to concerns more important to the white middle-class. They also warned that the newfound focus on environmentalism might distract the nation from the unsolved problem of discrimination's effects on African Americans and other racial minorities. ${ }^{10}$ Unfortunately, environmental regulators did not respond to this challenge. ${ }^{11}$

It has only been with the beginnings of the environmental justice movement, and in particular the 1982 Warren County protests, ${ }^{12}$ that issues of race, distribution, and fairness have been considered with the same seriousness and attention devoted to other environmental issues by regulators and environmentalists. Alleging racism in the disposal of highly hazardous polychlorinatedbiphenyl ("PCB") wastes in a predominately African American rural community, the protests demonstrated the salience of race and equity issues even within environmental protection. Yet regulators refused to intervene.

Such dramatic images and disturbing claims of racial discrimination led to studies by the General Accounting Office ("GAO"), ${ }^{13}$ the Commission for Racial Justice of the United Church of Christ, ${ }^{14}$ and others inquiring into the correlation of hazardous waste facility siting to the racial make-up of host communities. The GAO study found that of four offsite hazardous waste landfills located within the eight-state jurisdiction of EPA's Region IV, three were located in predominately African American communities even though they only made up twenty percent of the region's population. ${ }^{15}$ Among the key findings of the Commission for Ra-

only limit the benefits of municipal services such as sanitary sewers, street lighting, and potable water supplies, but arguably also shift undesirable facilities, such as waste facilities and polluting industries, to minority neighborhoods.

to See Lazarus, supra note 1, at 788-89.

${ }^{11}$ Id. at 789, 836-38 (discussing conscious decision by EPA to enforce anti-discrimination requirements of Title VI of the Civil Rights Act less than aggressively).

${ }^{12}$ See, e.g., Dale Russakoff, As in the '60s, Protesters Rally; But This Time the Foe Is $P C B$, WASH. Post, Oct. 11, 1982, at A1. In the Warren County, North Carolina, protests, a community made up predominantly of African American and poor individuals objected to the establishment of PCB waste disposal site within the county by engaging in civil rights movement-style acts of civil disobedience such as attempting to block the trucks carrying the hazardous waste. The community residents were unable to stop the establishment of the particular PCB waste disposal site itself.

Further accounts of the history and varied perspectives of the environmental justice movement can be found in UNequal PROTECTION: ENVIRONMENTAL JUSTICE AND COMMUNITIES OF COlOR (Robert D. Bullard ed., 1994) and Confronting ENvironmental RACISM: VOICES FROM THE GRASSROOTS (Robert D. Bullard ed., 1993).

${ }^{13}$ See GaO, Siting of Hazardous Waste Landfills and Their Correlation With Racial aNd ECONOMIC STATUS OF SuRRounding Communities (1983) [hereinafter Siting of HAzARDOUS WASTE LANDFILLS].

14 See Comm'n for Racial Justice (United Church of Christ), Toxic Wastes and Race in the United States: A National Report on the Racial and SocioECONOMIC Characteristics of CoMmunities WITH Hazardous Waste Sites (1987).

is See Siting of Hazardous Waste Landfills, supra note 13, at 2. 
cial Justice study were that "three of every five African and Hispanic Americans lived in communities with uncontrolled toxic waste sites" and that "race proved to be the most significant among variables tested in association with the location of commercial hazardous waste facilities."16 Other studies found similar disproportionate impacts. ${ }^{17}$

Later, a 1992 study by the National Law Journal, examining government enforcement of environmental laws at 1177 Superfund toxic waste sites, concluded that, "penalties under hazardous waste laws assessed at sites having the greatest white population were about 500 percent higher than penalties at sites with the greatest minority population." 18 The same study also found that, "[for] all the federal environmental laws aimed at protecting citizens from air, water and waste pollution, penalties in white communities were 46 percent higher than in minority communities." 19

The environmental movement itself has not been immune to the effects of prevailing attitudes about race and the neglect of discrimination, equity, and fairness concerns within its work. In fact, venerable organizations such as the Sierra Club had chapters during the first half of the twentieth century whose membership policies, in keeping with the prevailing attitudes of the day, were outright racist. ${ }^{20}$

Of course, open racism and bigotry have not been socially acceptable among most political liberals, including environmentalists, for some time. However, environmental justice activists also pointed out examples of more subtle, and perhaps inadvertent racism. For example, the organizational staff make-up of the major environmental organizations has been almost exclusively white. Furthermore, the concerns that they have championed in the past, such as wilderness and species preservation issues, have had little relevance for poor and minority communities. ${ }^{21}$

${ }^{16}$ See COMM'N FOR RACIAL JuSTICE, supra note 14 , at xiii-xiv.

${ }^{17}$ See, e.g., Benjamin Goldman \& Laura FitTon, Toxic Wastes and Race RevisITED: AN UPDATE OF THE 1987 RePorT OF THE RACIAL aNd SOCIOECONOMIC ChaRACTERISTICS OF COMMUNities With Hazardous Waste Sites (1994); Vicki Been, Coming to the Nuisance or Going to the Barrios? A Longitudinal Analysis of Environmental Justice Claims, 24 EcologY L.Q. 1 (1997); see also id., at 5 n.14 (listing numerous other studies reaching similar conclusions).

${ }^{18}$ Marianne Lavelle \& Marcia Coyle, Unequal Protection: The Racial Divide in Environmental Law, A Special Investigation, NAT'L L.J., Sept. 21, 1992, at S2.

${ }^{19}$ Id.

${ }^{20}$ See Charles Jordan \& Donald Snow, Diversification, Minorities, and the Mainstream Environmental Movement, in VOICES from the ENVIRONMENTAL MOVEMENT: PerspecTIVES FOR A NEw ERA 71, 75-78 (Donald Snow ed., 1992) (noting that the Sierra Club's California chapters prohibited membership by racial minority individuals up until the 1950s).

${ }^{21}$ See Mark Dowie, Losing Ground: American Environmentalism at the Close of The Twentieth Century 168 (1995); see also Victoria Slind-Flor, Amid Board Rancor, Sierra Club LDF Loses 2d Black: Staff Attorney Quits and Rekindles Dispute Over Environmental Racism, NAT'L L.J., Oct. 30, 1995, at A6 (discussing former Sierra Club Legal Defense Fund board member who equated the NAACP with a "black man's Ku Klux Klan" and described the role of an African American female judge as chair of the board as 
While most of these conditions were unlikely to be the result of outright racism, they did evince a significant lack of concern about racial discrimination and equity issues.

In light of the close parallels to the civil rights struggles of the 1950s and 1960s, then-Reverend Benjamin Chavis, Jr., coined the phrase "environmental racism" as the problem that the movement sought to address. ${ }^{22}$ Grass-roots organizing and growth of the movement around waste siting and other environmental issues eventually culminated in 1991 in the "First National People of Color Environmental Summit" and much greater national awareness about the problems of race and equity in environmental protection. ${ }^{23}$

Since then, the movement has been successful in prompting federal responses at a number of levels, as well as drawing responses from the environmental movement and academic interest. The Clinton Administration issued a Presidential Executive Order directing federal agencies to consider the environmental justice implications of their decisionmaking. ${ }^{24}$ EPA established both an Office of Environmental Justice and a federal advisory committee, and also promulgated a formal administrative complaint process with regard to disparate impact allegations under Title VI of the Civil Rights Act of 1964. Also, as a response to the movement, mainstream environmental organizations created projects and offices to address environmental justice concerns. ${ }^{25}$ Academic attention to this issue has mushroomed. ${ }^{26}$

Yet the problems of race and equity raised by the environmental justice movement have remained intractable. ${ }^{27}$ And the most recent contro-

“'interesting' because in the 40 years I have worked intensely in environmental matters, I have found total disinterest among children or adults of your race in environmental matters").

${ }^{22}$ According to Chavis:

Environmental racism is racial discrimination in environmental policymaking, the enforcement of regulations and laws, the deliberate targeting of communities of color for toxic waste facilities, the official sanctioning of the life-threatening presence of poisons and pollutants in our communities, and the history excluding people of color from leadership of the environmental movement.

Karl Grossman, The People of Color Environmental Summit, in Unequal Protection: Environmental Justice and Communities of Color 272 (Robert D. Bullard ed., 1994). See also Rev. Benjamin F. Chavis, Jr., Foreword, in Confronting EnvironMENTAL RACISM: VoICES FROM THE GRASSROOTS 3 (Robert D. Bullard ed., 1993).

${ }^{23}$ See Grossman, supra note 22, at 274-75; see also Down, supra note 21, at 151-55.

${ }^{24}$ Exec. Order No. 12,898, 59 Fed. Reg. 7629 (Feb. 14, 1994).

${ }^{25}$ See Down, supra note 21, at 169.

${ }^{26}$ See, e.g., Carita Shanklin, Pathfinder: Environmental Justice, 24 EcoloGy L.Q. 333 (1997); Robert W. Collin, Review of the Legal Literature on Environmental Racism, Environmental Equity, and Environmental Justice, 9 J. ENVTL. L. \& LITIG. 121 (1994).

${ }^{27}$ While many have seen the environmental justice movement as focusing on pollution control and toxic substance issues, similar discrimination and fairness issues have arisen in the land and natural resource management context. For example, Native Americans have been affected through conquest and displacement from their aboriginal lands, see generally 
versies, involving EPA's guidance to its regulations under Title VI of the Civil Rights Act as well its 1998 Select Steel decision, seem to amply bear out these difficulties.

At one level, it should be apparent that the necessary political commitment to these issues is lacking. However, given the genuine and sincere concern expressed by regulators about the problems raised by the environmental justice movement, it would also be unfair to attribute these difficulties to bureaucratic recalcitrance or bigotry. Rather, many of the difficulties can be traced back to differences in how environmental justice activists and regulators view environmental justice and what they understand the role of the regulatory system to be in addressing them. The paradigms under which each group has operated provide much insight in this regard.

\section{The PARAdIgms}

There are three paradigms that I will rely on in my analysis. Two of them have had an enormous impact on shaping our understanding of environmental regulation: the "prisoner's dilemma" problem that Garrett Hardin applied to the environmental commons ${ }^{28}$ and Rachel Carson's insights into the unexpected effects of environmental degradation and the interdependent relationships within nature. ${ }^{29}$ These two paradigms will be contrasted with the paradigm of prejudice and government involvement in discrimination that were the premises of Brown v. Board of Education, the case that marked a turning point in modern civil rights law and the mandates of the equal protection clause.

Rennard Strickland, Genocide-at-Law: An Historic and Contemporary View of the Native American Experience, 34 Kans. L. Rev. 713, 733-34 (1986); DavID H. GetcheS ET AL., Cases and Materials on Federal Indian Law 41-191 (1998); Mexican Americans through defeat during the Mexican American war and subsequent forfeiture of lands, see generally Perea et AL., RACE ANd RACes: CASES ANd Resources for a Diverse AMERICA 270-75 (2000); Guadalupe T. Luna, Chicana/Chicano Land Tenure in The Agrarian Domain: On the Edge of a "Naked Knife," 4 Mich. J. RACE \& L. 39 (1998); Japanese Americans, prior to World War II internment, see United States v. Korematsu, 323 U.S. 214,216 (1944), through alien land laws restricting land ownership, see generally Keith Aoki, No Right to Own?: The Early Twentieth-Century "Alien Land Laws" as a Prelude to Internment, 40 B.C. L. Rev. 37 (1998); and African American slaves, beyond the simple support and enforcement of slave status, also through other disabilities, such as restrictions on their right to own property, see, e.g., Bill Quigley \& Maha Zaki, The Significance of Race: Legislative Racial Discrimination in Louisiana, 1803-1865, 24 S.U. L. REv. 145, 174 (1997). It would be much beyond the scope of this Article to review the history of conquest, subjugation, discrimination, and exploitation of racial minorities in the struggle for land and resources in greater detail.

${ }^{28}$ See HARDIN, supra note 5.

${ }^{29}$ But see E. Donald Elliott et al., Toward a Theory of Statutory Evolution: The Federalization of Environmental Law, 1 J.L. ECON. \& ORG. 313 (1985) (providing a historical interpretation of the enactment of environmental statutes as a consequence of politically self-interested actions by President Richard M. Nixon and Senator Edwin Muskie). 


\section{A. The Influence of Garrett Hardin and Rachel Carson on Environmental Protection}

The conventional justification for environmental regulation is that it is a necessary response to market failures in the use of natural resources or the disposal of pollutants. The classic explication of the market failure thesis was put forth by Garrett Hardin in The Tragedy of the Commons..$^{30}$ According to Hardin, unregulated and unrestricted access to scarce common resources creates a dynamic of exploitation by its users. Selfinterest and the inability to exclude each other from the commons drives a group of rational individuals to use the resource beyond a level that is optimal with regard to benefits and costs for the group as a whole.

Hardin's example in The Tragedy of the Commons posited a situation where a common cattle pasture is used at its carrying capacity, i.e., at the maximum number of cattle that the pasture can support (a resource's maximum use) without experiencing an overall decline in productivity. Any more intensive use of the land, i.e., adding one more animal to the pasture beyond its carrying capacity, would result in an overall net loss of utility from the use of the land.

In such a situation, a cattle herder who seeks to maximize his gain from use of the common pasture would face the following decision calculus: He would receive all of the benefits, such as proceeds of the prospective sale, of an additional animal that is allowed to graze on the communal pasture. At the same time, he would only bear a fraction of the effects of overgrazing since that burden is shared by all pasture users. The rational action of a self-interested individual, the quintessential economic actor, would be to add another animal to the pasture. That, of course, results in an overall net loss of utility to the entire group of herders utilizing the pasture. ${ }^{31}$ Yet the action would provide a net benefit to the individual herder. Since every user of the pasture faces the same decision calculus, the communal pasture ends up being greatly overused, and the entire community suffers as a result. ${ }^{32}$

Strictly speaking, Hardin was not the first to discover the problem of collective action dynamics. ${ }^{33}$ Nor was he the first to understand the prob-

${ }^{30}$ Hardin, supra note 5.

${ }^{3 !}$ Id. at 1244.

${ }^{32}$ The same dynamic can occur with regard to pollution problems, such as the disposal of pollutants into the air and water bodies and the consequent sharing of the effects of such pollution by all. Id. at 1245 .

${ }^{33}$ See Mancur Olson, Jr., The Logic of Collective Action: Public Goods and THE THEORY OF GROUPS (1965). Hardin's description of the "tragedy of the commons" is a specific application of the cooperation difficulties that are presented by choices which may maximize the gains for any particular individual but would not be optimal for others in a collective group of individuals with the same choice, a problem that is most commonly described by the "prisoner's dilemma." See generally ROBERT AXELROD, THE EVOLUTION of CoOperation (1984); see also William H. Rodgers JR., ENVIRONMENTAL LAW 39-42 (2d ed., 1994). 
lem of environmental externalities that environmental degradation of common resources presents. ${ }^{34}$ Nor has Hardin's The Tragedy of the Commons been without its critics. ${ }^{35}$ However, it has been his conception that has driven modern environmental regulation and led to approaches seeking to force polluters to bear the costs of the pollution harms they create.

But if Garrett Hardin's seminal The Tragedy of the Commons led regulators to focus on the underlying economics of environmental degradation, Rachel Carson's book Silent Spring ${ }^{36}$ forced environmentalists to look at the ecological and scientific basis of environmental harm and to understand that the problems causing environmental degradation were intertwined. ${ }^{37}$

The roots of the idea that nature and humans are interconnectedpart of the same web of life-can be traced to many philosophies and religions, including Native American religion and culture, ${ }^{38}$ and, more recently, the deep ecology movement. ${ }^{39}$ Nevertheless, the modern incarnation of this idea responsible for exerting a significant influence on current-day thinking about environmental regulation, has in large part, been attributed by many scholars to Rachel Carson..$^{40}$ Her focus on the interconnection of the natural environment through various ecological relationships and pathways and the unavoidable connection of humans to the environment is seen by some as one of the most important triggers for our modern pollution control system.

In her 1962 book, Carson detailed the unintended side-effects that pollution of the air, water, and land by chemicals and pesticides, in particular by the pesticide dichloro-diphenyltrichloroethane("DDT"), had on

${ }^{34}$ See, e.g., A.C. Pigou, The Economics of Welfare (1932).

${ }^{35}$ See, e.g., Carol Rose, The Comedy of the Commons: Custom, Commerce, and Inherently Public Property, 53 U. ChI. L. Rev. 711 (1986); RoberT C. Ellickson, ORder Without Law: How Neighbors Settle Disputes (1991). See also Ronald Coase, The Problem of Social Cost, 3 J.L. \& ECoN. 1 (1960) (examining Pigou's premise that differing liability rules affect the economically efficient use of resources).

${ }^{36}$ CARSON, supra note 6.

${ }^{37}$ Carson, of course, did not do much of the original research to document the harmful effects of pesticide that she discussed, nor was she the first to write about them. See PHILIP Shabecoff, A Fierce Green Fire 109 (1993).

${ }^{38}$ See, e.g., Deward E. Walker, Jr., Protection of American Indian Sacred Geography, in Handbook of American Indian Religious Freedom 100 (Christopher Vecsey ed., 1991); see also J. Baird Callicott, American Indian Land Wisdom, in THE STRUGgLE FOR THE LAND: Indigenous InSIGHT and INDUSTRIAL EMPIRE IN THE SEMIARID World 255 (Paul A. Olson ed., 1990).

${ }^{39}$ See, e.g., Bill Devall, The Deep Ecology Movement, 20 NAT. Resources J. 299 (1980), James Lovelock, The Ages of Gaia: A Blography of Our Living Earth (1988); see also Aldo Leopold, A Sand County Almanac (1949). For an exploration of the ethical origins of environmentalism, see Roderick F. NASH, THE Rights Of NATURE: A History OF ENVIRONMENTAL ETHICS (1989).

to See, e.g., J. William Futrell, The History of Environmental Law, in ENVIRONMENTAL LaW: From Resources to Recovery 2, 32-33 (Celia Campbell-Mohn et al. eds., 1993); Plater, supra note 4, at 998-1004; Lakshman Guruswamy, Integrating Thoughtways: ReOpening of the Environmental Mind?, 1989 WIS. L. REv. 463, 509 (1989). 
the natural environment. By raising public awareness about the various pathways and interconnections through which chemicals spread throughout nature, including to humans, she raised disturbing questions about the hidden dangers that indiscriminate pesticide and chemical use presented. Her book alerted environmentalists, regulators, and the public to these important environmental linkages and how the adverse impacts of pesticides on one part of the ecological system, such as on target weeds and pests, can have unexpected and far-reaching effects on other organisms and animals.

Carson's book was controversial at the time of its publication. However, modern science and ecology have confirmed many of her assertions. ${ }^{41}$ These conclusions have come to be seen as more broadly applicable to the need to address environmental problems comprehensively and in a scientifically and technically sound fashion. For example, the modern comprehensive environmental statutes have tried to heed such thinking, though imperfectly, by creating enormous regulatory structures at both the state and federal level. ${ }^{42}$ Through the years, calls for stronger incorporation of this recognition have continued, ${ }^{43}$ finding their modern manifestation in the drive to address environmental problems internationally, regardless of political boundaries.

Modern environmental regulation is thus based on the following paradigm: environmental degradation is a problem caused by the rational behavior of human beings in pursuit of individual gain and benefits. Damage of such degradation to one part of the ecological system can have unexpected, significant, and far-reaching impacts on other parts of the ecological system. Regulation is necessary to correct failures by the free market and independent individual actions to promote the common good. At the same time, regulation cannot occur in a limited and discrete fashion, but must be carried out by an integrated and comprehensive scheme in order to be effective.

\section{B. The Influence of Brown v. Board of Education on Civil Rights Law}

The problem paradigm upon which civil rights law has been premised, Brown v. Board of Education, ${ }^{44}$ has quite different characteristics. Brown, as it is commonly known, brought an end to officially sanctioned racial segregation in public education and heralded the demise of the

${ }^{41}$ See RoDGERS, supra note 33, at 400-03.

${ }^{42}$ See, e.g., Clean Air Act, 42 U.S.C. \$\$ 7401-7641 (2001). As another example, the Resource Conservation and Recovery Act, 42 U.S.C. $\$ \S 6901-6992 k$ (2000), instituted "a comprehensive environmental statute that empowers EPA to regulate hazardous wastes from cradle to grave." City of Chicago v. Envtl. Def. Fund, 511 U.S. 328, 331 (1994).

${ }^{43}$ See, e.g., Arnold W. Reitze, Jr., Environmental Policy-It Is Time for a New Beginning, 14 Colum. J. ENvTL. L. 111 (1989); Guruswamy, supra note 40, at 492-516.

44347 U.S. 483 (1954). 
"separate but equal" doctrine. But at a deeper level, Brown's reliance on the Constitution's promise of racial equality and the role of the courts in protecting the rights of racial minority groups also set out a paradigm that is quite at odds with the paradigms relied upon by environmental regulators.

Brown found that even though white and African American schools in racially segregated public school systems had "been equalized, or are being equalized, with respect to buildings, curricula, qualifications and salaries of teachers, and other 'tangible' factors," 45 a determination of whether such schools accord the African American children with the equal protection of the laws could not "turn on merely a comparison of these tangible factors." 46 Rather, consideration of the "effect of segregation itself on public education" was mandated ${ }^{47}$ Since segregation itself was designed to provide official legal sanction to the notion that one race was inferior to the other and to impart that notion to school children, segregation deprived the children of the minority group of the equal protection of the laws. "[I]n the field of public education, the doctrine of 'separate but equal' has no place. Separate education facilities are inherently unequal." 48

At a deeper level, Brown's reliance on the Constitution's promise of racial equality also emphasized the role of the courts in protecting the rights of racial minority groups, even if it meant that contrary interests and desires of the political majority were thwarted. At the same time, the law's solicitude toward the rights of racial minorities reached far beyond particular tangible harms. Thus, maintenance of a system of racial segregation, even though other tangible factors between white and African American schools were equal, was still illegal. ${ }^{49}$ Segregation's message of inequality among the races and the notion that one race was inherently inferior to the other were themselves inconsistent with the equal protection clause. ${ }^{50}$

Brown was, of course, not the first case in which the Supreme Court had found an aspect of segregation to be constitutionally impermissible. ${ }^{51}$ However, it was the first instance in which the Court faced the constitutionality of segregation as a government policy forthrightly and banished racial segregation not only from public schools but also all other areas of government. $^{52}$

${ }^{45} I d$. at 492.

${ }^{46} I d$.

${ }^{47} \mathrm{Id}$.

${ }^{48} I d$. at 495.

${ }^{49}$ See Brown, 347 U.S. at 492.

${ }^{50}$ See id. at 495.

"See, e.g., Sweatt v. Painter, 339 U.S. 629 (finding that a segregated law school for African Americans could not provide them equal educational opportunities). (1979).

52 See, e.g., Owen M. Fiss, Foreword: The Forms of Justice, 93 HARv. L. REv. 1, 2-4 
Brown has not been without its critics. In spite of its tremendous impact on the permissibility of government-sponsored discrimination, Brown and its progeny cases have been criticized for being less than fully effective in actually undoing the consequences of such discrimination. ${ }^{53}$

In fact, Brown's focus on the Fourteenth Amendment's provision that "[n]o state shall ... deny to any person within its jurisdiction the equal protection of the laws" and on how segregation in public education violated the prohibition ${ }^{54}$ conceived of discrimination not only as actions by government entitities but also as the result of specific actions with evil intent. After all, the equal protection clause did not specifically speak to the effects of discrimination. Rather, it prohibited the active engagement in discrimination-the denial of equal protection-by states. In that sense, it foreshadowed many of the limitations that later cases would impose on the reach of much anti-discrimination law, in particular discrimination that did not result from any specifically identifiable actor. ${ }^{55}$

As a result, the Brown paradigm gave us a picture of discrimination that was particularly concerned not only with protecting minorities against the whims of the majority, but also emphasized that the intangible aspects of discrimination were just as important to the law as the tangible ones. At the same time, the Brown paradigm led to a model of civil rights law that was quite limited in its vision of the role of the law and government in protecting minorities.

\section{Putting the Paradigms Together}

The characteristics of the paradigms have had a special significance with regard to the concerns of the environmental justice movement. The problem that Brown and its civil rights progeny have sought to avoidminority oppression by the majority-has been antithetical to the concerns of environmental regulators, who have largely seen their mission as the protection of the majority against the self-interested actions of the individual or small special interest groups. Their differing regulatory structures reflect these differing concerns through the roles that they assign to courts, administrative agencies, and state and local governments.

${ }^{53}$ See, e.g., Alan David Freeman, Legitimizing Racial Discrimination Through Antidiscrimination Law: A Critical Review of Supreme Court Doctrine, 62 MiNN. L. Rev. 1049 (1978).

${ }^{54}$ Brown, 347 U.S. at 491-93 (focusing on public education and the notion that "education is perhaps the most important function of state and local governments").

${ }_{55}$ Discriminatory impact is insufficient to establish equal protection violations. See Washington v. Davis, 426 U.S. 229 (1976); Arlington Heights v. Metro. Hous. Dev. Corp., 429 U.S. 252 (1977). Some statutory civil rights provisions do reach disparate impacts not directly connected to identifiable bigoted actions, though they tend to be the exception. See, e.g., Guardians Ass'n v. Civil Serv. Comm'n, 463 U.S. 582, 584 n.2 (1983) (acknowledging that Title VI of the Civil Rights Act of 1964 allows federal agencies to promulgate and implement regulations prohibiting discriminatory impacts). 
At the same time, the paradigms have also led to different methodological approaches to regulation. By pointing to the importance of economic analysis and scientific knowledge, environmental regulation has heavily emphasized quantitative approaches to regulation. In contrast, Brown's focus on intangibles and unquantifiables has stressed the significance of incommensurables.

Finally, Brown's emphasis on the government-sponsored and intentional aspects of discrimination foreshadowed the limited scope of civil rights law as a solution to discrimination more generally. In stark contrast, the idea of the interconnectedness of environmental problems under Hardin's and Carson's paradigms has promoted a strong ideal of regulatory comprehensiveness.

\section{The Challenge of Environmental Justice to THE ENVIRONMENTAL REgUlatory PARADIGM}

\section{A. The Problem of Minority Protection and the Empty Promise of Devolution and Local Control for Environmental Justice}

Under Garrett Hardin's explication of "the tragedy of the commons," the quintessential focus of environmental regulation is on actions by individuals that, while advantageous and beneficial to that particular individual, are harmful for the community overall. The result is that environmental regulation, like many other forms of government regulations, is primarily directed at protecting the collective from the irresponsible or selfish actions of individuals or small groups.

That perspective is entirely reversed in anti-discrimination law. The underlying premise of Brown v. Board of Education is that prejudice and minority oppression requires the law to focus its protections on minority groups against the majority. Because it was necessary to protect African Americans against continuing discrimination and oppression by whites following the Civil War, the Fourteenth Amendment's Equal Protection Clause was specifically designed to be counter-majoritarian in character. ${ }^{56}$

The regulatory structures within environmental law and civil rights law have reinforced these divergent goals. Environmental protection is promoted largely through administrative agencies controlled by the po-

${ }^{56}$ Of course, under normal democratic processes, almost every individual or group inevitably ends up on the losing side of a government decision eventually. However, prejudice and other impediments to normal political and legislative coalition-building can create dynamics within which particular groups, such as racial minorities, are unable to utilize the political process to protect themselves against consistently unfair treatment by the majority. See United States v. Carolene Prods., 304 U.S. 144, 152-53 n.4 (1938). See generally John Hart Ely, Democracy and Distrust: A TheORy of Judicial Review 145-70 (1980). 
litical branches while the rights of minorities are safe-guarded through the counter-majoritarian courts. ${ }^{57}$

These divergent understandings are also at the heart of much criticism by environmental justice advocates that many health and environmental standards are insufficiently protective of racial minorities and the poor. Precisely because regulatory standards are intended to achieve the greatest good for the greatest number of people, such standards fail to take into account the special characteristics and vulnerabilities of minority populations and the poor. ${ }^{58}$

For example, studies have shown that some poor and racial minority groups consume significantly more fish caught in contaminated water bodies than their white, male counterparts because of their reliance on it as an important subsistence supplement to their diet. ${ }^{59}$ Yet, pollution limits set by agencies to protect humans from toxins accumulated in fish have traditionally been based on the consumption patterns of white, male sport fishers. Not surprisingly, racial minority groups and the poor have suffered exposure to much higher levels of pollutants and toxins. ${ }^{60}$

The failure of environmental law to sufficiently consider the special needs of minority groups also explains the problems associated with devolving control over environmental decision-making, in particular the siting of hazardous waste facilities, to local governments.

Delegating waste facility siting decisions to local government bodies has occurred in part as a response to discrimination claims and concerns about the lack of local community input into such siting decisions. The goal of such efforts has been to increase the affected community's par-

${ }^{57}$ For a discussion of courts and adjudication as mechanisms for regulation, see CAss R. Sunstein, After the Rights Revolution: Reconceiving the Regulatory State 111-59 (1990); Colin S. Diver, Policymaking Paradigms in Administrative Law, 95 HARv. L. REv. 393, 403-09 (198I) (describing common law adjudication as incremental regulation); Lon L. Fuller, The Forms and Limits of Adjudication, 92 HARv. L. REv. 353, 357 (1978). What I call majoritarian orientation others have referred to as pluralistic. See, e.g., Gauna, supra note 4, at 19-28.

${ }^{58}$ See Robert R. Kuehn, The Environmental Justice Implications of Quantitative Risk Assessinent, 1996 U. ILL. L. REv. 103, 121-29 (1996). Some commentators have attributed the law's shortcomings in protecting racial minorities primarily to the obstacle that the discriminatory intent requirement that Washington v. Davis, 426 U.S. 229 (1976), imposes for most discrimination remedies. See, e.g., Rachel Godsil, Remedying Environmental Racism, 90 Mich. L. REv. 394, 408-09 (1991). While that description is, of course, accurate in its reference to a particular doctrinal deficiency, a singular focus on this doctrinal aspect obscures the deeper and more fundamental structural shortcomings of civil rights law that this doctrinal shortcoming evidences. See infra discussion in Part IV.C.

${ }^{59}$ See Patrick West et al., Minorities and Toxic Fish Consumption: Implications for Point Discharge Policy in Michigan, in Environmental Justice: Issues, Policies, AND Solutions 124 (Bunyon Bryant ed., 1995).

${ }^{60}$ See, e.g., Catherine A. O'Neill, Variable Justice: Environmental Standards, Contaminated Fish, and "Acceptable" Risk to Native Peoples, 19 STAN. EnVtL. L.J. 3, 11-14 (2000). A similar case can be made with regard to the toxic exposures of farmworkers, many of whom are members of racial minority groups. See, e.g., GAO, PESTICIDES-IMprovements NeEded to Ensure the Safety of Farmworkers and Their Children (2000). 
ticipation within the siting process. However, commentators who have examined such local government-based approaches have been critical of their practical effectiveness. ${ }^{61}$ In many instances, such measures have not been able to resolve the complaints of adversely affected minority communities.

An examination of the paradigms explains why. Brown's scrutiny of state-sponsored intentional discrimination has led to a structural distrust of state and local governments regarding the protection of racial minorities that finds no equivalent in the cooperative partnership between the federal government and states in environmental regulation. This distrust should not come as a surprise in light of the long history of exploitation and victimization of racial minorities, during periods of time when management of environmental issues, including land and natural resource use, was in fact largely controlled by state and local governments. The reality has been that within such local government entities, government officials have not been particularly responsive or politically accountable to racial minority groups and the poor for a variety of reasons. ${ }^{62}$

That is not to say that such approaches have entirely failed, and some successes have been documented. But such successes can be expected to be the exception rather than the norm. ${ }^{63}$ After all, even in the absence of racial prejudice, it may be simply too much to expect state and local governments to act contrary to political pressures of powerful local political constituencies or majority sentiments to maximize economic development and to attract jobs. This will be especially true during times of economic hardship, when looking beyond self-interest to the needs of the politically weak and disenfranchised will be particularly difficult. In many ways, relying on states or local governments to resolve

${ }^{61}$ See, e.g., Godsil, supra note 58, at 402-08; Luke Cole, The Theory and Reality of Community-based Environmental Decisionmaking: The Failure of California's Tanner Act and Its Implications for Environmental Justice, 25 ECOLOGY L.Q. 733 (1999); see also Kenneth Manaster, Environmental Protection and Justice: Readings and ComMENTARY ON ENVIRONMENTAL LAW AND PRACTICE 200-09 (1995).

${ }^{62}$ Within such local government entities, racial minorities may constitute a minority of voters or otherwise may not be able to wield much political influence. See, e.g., City of Richmond v. J.A. Croson Co., 488 U.S. 469, 522-23 (1989) (Scalia, J., concurring) (quoting The Federalist No. 10, 82-84 (Clinton Rossiter ed., 1961) (citations omitted):

The struggle for racial justice has historically been a struggle by the national society against oppression in the individual States. And the struggle retains that character in modern times .... "The smaller the society, the fewer probably will be the distinct parties and interests composing it; the fewer the distinct parties and interests, the more frequently will a majority be found of the same party; and the smaller the number of individuals composing a majority, and the smaller the compass within which they are placed, the more easily will they concert and execute their plan of oppression."

${ }^{63}$ See, e.g., Cole, supra note 61 (examining instances of success and failures of local control approaches). 
discrimination issues resembles the old adage of asking the fox to guard the hen house.

\section{B. Quantitative Analysis and the Importance of Intangibles}

The paradigms have also had an important influence on the role that quantifiable and intangible values have played in regulation. Both Carson's Silent Spring and Hardin's Tragedy of the Commons have led to an increased reliance on quantifiable, measurable considerations.

Carson's account of pesticides illustrated all too clearly the lack of understanding humans have had of the effects of such chemicals and, more broadly, about the wider impacts of pollution and environmental degradation on the ecological system. While her message was one of caution, regulators also saw a solution within the warning she raised. If our lack of knowledge about the impacts of environmental degradation and the intricate interconnections of the natural world was one reason for environmental harm, the solution to preventing harm and restoring the environment would surely be better scientific understanding of environmental problems. The scientific view of environmental problems has accordingly led to an increased reliance on scientific and technical analysis to understand and solve environmental degradation problems.

Hardin's model of environmental degradation as a consequence of rational self-interest and market failure has had similar consequences. Essentially an economic explanation for environmental degradation, this paradigm's influence has come from its ability to explain environmental degradation and the behavior of industrial entities so well. Use of economic analysis has given environmental regulators a tool to balance the benefits of environmental protection with the costs of pollution reducing technologies and the foregone benefits of industrial resource use and pollution.

Scientific and economic analysis of environmental problems has provided some important analytical clarity and improved environmental decision-making in many respects. However, it has also undermined environmental regulation because of its heavy reliance on quantifiable information as the most important input for decision-making. ${ }^{64}$ Intangibles or incommensurables are generally left out of the analysis. The importance of scientific uncertainty, the unknown, and other factors, such as process and distributional values, are devalued. ${ }^{65}$ And since quantifiables tend to

G See Richard B. Stewart, The Reformation of American Administrative Law, 88 HARv. L. REv. 1669, 1704-11 (1975).

"s See, e.g., Howard Latin, Ideal Versus Real Regulatory Efficiency: Implementation of Uniform Standards and "Fine-Tuning" Regulatory Reforms, 37 STAN. L. REv. 1267 (1985) (suggesting that the pervasiveness of uncertainty in environmental regulation significantly diminishes the effectiveness of economic analysis in achieving environmental protection goals); Donald T. Hornstein, Reclaiming Environmental Law: A Normative Critique of 
be more impressive, easy to grasp, and easy to identify, they overpower and dominate the unquantifiable aspects of the regulatory decisionmaking process. The result has been that even if the quantitative analysis is true to the input, it is also a construct of reality that provides only partial answers. And while the overall outcome is suspect as a result of ignoring qualitative factors, it nevertheless possesses the mantle of precision and objectivity. ${ }^{66}$

Of course, quantifiable economic impacts and other practical consequences of discrimination were also significant to the life experiences of racial minorities during segregation by limiting the economic, educational, and other opportunities and avenues available to them. At a minimum, it simply made life more expensive and created obstacles to improving one's economic welfare ${ }^{67}$ It is unlikely that such considerations were not also an important target of anti-discrimination laws.

However, in civil rights law, the focus is on the incommensurablesespecially the importance of the value of equality. Brown made this clear when it declared that even if 'the physical facilities and other 'tangible' factors may be equal, ... [s] eparate educational facilities are inherently unequal." ${ }^{\prime 68}$ Justice Goldberg once stated of the Civil Rights Act of 1964, that its "primary purpose ... is the vindication of human dignity and not mere economics." 69

Comparative Risk Analysis, 92 Colum. L. Rev. 562, 592-603 (1992) (arguing that risk analysis is a poor substitute for necessary moral judgments about environmental protection).

Of course, criticisms of the use of economic analysis and assertions about the importance of ethical concerns about nature and other intangible values have abounded in the past. See, e.g., Robert Percival et al., Environmental Regulation: Law, Science, AND Policy 68-69 (1996); see also Mark Sagoff, The Principles of Federal Pollution Control Law, 71 MinN. L. REv. 19, $24-44$ (1986); Mark Sagoff, Can Environmentalists Be Liberals? Jurisprudential Foundations of Environmentalism, 16 ENVTL. L. 775, 782-83 (1986) (describing environmentalist appeals to the "rights and interests of animals and other natural things" as the environmental equivalent of deontology according to Kant); Laurence H. Tribe, Ways Not to Think about Plastic Trees: New Foundations for Environmental Law, 83 YALE L.J. 1315 (1974).

In addition, an understanding of the unquantifiable values of wildlife and nature has found its expression in various natural resources statutes, such as the Endangered Species Act, 16 U.S.C. $\$ \$ 1531-1544$ (1994), and the International Dolphin Conservation Program Act, Pub. L. No. 105-42, 111 Stat. 1122 (1997). See also Mark Sagoff, Settling America or the Concept of Place in Environmental Ethics, 12 J. ENERGY NAT. RESOURCES \& ENvTL. L. 349 (1992).

However, in spite of such significant contributions to environmental regulation of moral and other intangible values, they represent only a minority tradition. The most visible, if not the most important, justifications for federal environmental legislation have been market failure and economic efficiency concerns.

${ }^{66}$ See Laurence H. Tribe, Trial by Mathematics: Precision and Ritual in the Legal Process, 84 HARv. L. REv. 1329, 1358-68 (1971).

${ }^{67}$ See, e.g., Heart of Atlanta Motel, Inc. v. United States, 379 U.S. 241, 252-53 (1964) (illustrating the difficulties that segregation and discrimination imposed on African American travelers).

${ }^{68}$ Brown v. Board of Education, 347 U.S. 483 (1954).

${ }^{69}$ Heart of Atlanta Motel, 379 U.S. at 291 (1964) (Goldberg, J., concurring). 


\section{The Controversy over EPA's Definition of Environmental Justice}

The problem of giving proper weight to qualitative factors has manifested itself prominently in debates about how environmental justice ought to be defined. One early EPA report, issued in 1992, is illustrative. In this report, EPA utilized the term "environmental equity" to convey its understanding and view of environmental justice concerns:

Environmental equity refers to the distribution of environmental risks across population groups and to our policy responses to these distributions. While there are many types of equity, all of which are important to EPA, ... this report focuses on racial minority and low-income populations ....

EPA chose the term environmental equity because it most readily lends itself to scientific risk analysis. The distribution of environmental risks is often measurable and quantifiable. The Agency can act on inequities based on scientific data. Evaluating the existence of injustices and racism is more difficult because they take into account socioeconomic factors in addition to the distribution of environmental benefits that are beyond the scope of this report. Furthermore, environmental equity, in contrast to environmental racism, includes the disproportionate risk burden placed on any population group, as defined by gender, age, income, as well as race. ${ }^{70}$

This singular focus on the distribution of pollution harms and risks has been criticized by environmental justice advocates as missing their point. ${ }^{71}$

To activists, environmental justice is a much more holistic concept that includes the right to a safe, healthy, productive, and sustainable environment for all. In this context, the "environment" is considered to include the ecological, physical, social, political, aesthetic, and economic environments. Environmental justice thus refers to the conditions in which such a right can be freely exercised, whereby individual and group identities, needs, and dignities are preserved, fulfilled, and respected in a way that provides for self-actualization and personal and community empowerment. ${ }^{72}$

${ }^{70}$ EPA, Environmental Equity: Reducing Risk for All Communities 2, 10 (1992).

${ }^{71}$ See, e.g., Luke W. Cole, Empowerment as the Key to Environmental Protection: The Need for Environmental Poverty Law, 19 ECOLOGY L.Q. 619, 641 (1992); Eileen Gauna, Federal Environmental Citizen Provisions: Obstacles and Incentives on the Road to Environmental Justice, 22 ECOLOGY L.Q. 1, 27-29 (1995).

72 See First Nat'l People of Color Envtl. Leadership Summit, Principles of Environmental Justice (1991), reprinted in MARK Dowie, Losing Ground, supra note 
The contrast between the two views is remarkable. The EPA's technocratic definition focuses almost exclusively on quantifiable and measurable aspects of risk distribution. In contrast, the activist definition encompasses holistic considerations ranging from ecological and physical factors to political and aesthetic ones. In a sense, what activists have been looking for are not just the minimum conditions necessary for human survival but also factors necessary for human thriving and quality of life. Concerns such as providing for aesthetically appealing and livable communities, places where pollution, odors, and traffic associated with industrial facilities do not make it impossible to enjoy and play in one's backyard, connect with neighbors, and have a good night's sleep are therefore indispensable. ${ }^{73}$

Activists see the difference between the two views not just as a simple misunderstanding or difference in views of the environmental justice movement's goals. Rather, they perceive it as an attempt at undermining the movement. By defining environmental justice in analytically familiar terms that could easily be incorporated into its way of doing business, the radical nature of the environmental justice movement and the challenge it posed to traditional environmental regulation could be neutralized and subverted.

To its credit, since that 1992 report, EPA appears to have taken the activists' criticism to heart, and its official view of environmental justice has moved considerably closer to encompassing intangibles. ${ }^{74}$ However,

21, at 284-85; see also Karl Grossman, The People of Color Environmental Summit, in Unequal Protection: Environmental Justice and Communities of Color, supra note 12 , at $274-75$.

${ }^{73}$ For example, a largely poor and minority community in Chester, Pennsylvania tells of the following:

During the summer, the stench and noise force residents to retreat into their dwellings. Recent visitors to Chester are quoted as saying that the "air is thick with acrid smells and, often, smoke. Dump trucks rumble through throughout the day, and the first thing you notice is the smell." ... [H]uge trucks . . would rumble through their neighborhoods at all times of the day and night, disturbing their sleep and their children's recreational time, and damaging the overall character and peace of their community. Noise and vibration from the constant stream of waste trucks have caused the foundations of nearby houses to crack and property values to plummet. Residents have felt imprisoned in their own community.

Sheila Foster, Justice From the Ground Up, 86 CAL. L. Rev. 775, 780 (1998).

${ }^{74}$ See EPA, Environmental Justice, at http://es.epa.gov/oeca/main/ej/index.html (last visited Oct. 5, 2001) (on file with the Harvard Environmental Law Review):

Environmental Justice is the fair treatment and meaningful involvement of all people regardless of race, color, national origin, or income with respect to the development, implementation, and enforcement of environmental laws, regulations, and policies. Fair treatment means that no group of people, including a racial, ethnic, or socioeconomic group, should bear a disproportionate share of the negative environmental consequences resulting from industrial, municipal, and commercial operations or the execution of federal, state, local, and tribal programs 
EPA's heavy reliance on technical and quantitative analysis in the processing of administrative complaints under its regulations implementing Title VI of the Civil Rights Act casts considerable doubt on whether EPA's change is real. ${ }^{75}$

\section{The Select Steel Decision and the Problem of Expert Agency Decisionmaking}

The failure to take seriously the significant burden that some intangible and incommensurable aspects of environmental regulation can impose on the poor and minorities also explains some of the difficulties that EPA has encountered in adapting its administrative processes to environmental justice claims. This has been apparent in the only on-themerits EPA decision to date regarding allegations of discrimination under EPA's disparate impact regulations implementing Title VI of the Civil Rights Act.

In the Select Steel matter, EPA found that concerns regarding the air quality impacts of a proposed steel recycling mini-mill in Genesee, Michigan did not rise to the level of discriminatory impacts within the meaning of Title VI and EPA's implementing regulations. ${ }^{76}$ In dismissing the administrative complaint, EPA relied largely on findings that individual emissions of various pollutants, including volatile organic compounds, lead, air toxics, and dioxin would not lead to violations of applicable national ambient air quality standards and other state requirements.

EPA's decision has been criticized for being based on factually wrong premises. ${ }^{77}$ But more importantly, the focus on particular quantifiable pollutants raises the question of whether compliance with standards adequately addresses the complainants' concerns about the proposed steel mill's impact on the community. After all, EPA's analytical approach ignores not only non-quantifiable and intangible impacts, but also the overall cumulative effect of such intangible and various quantifiable impacts in the aggregate. And it is the totality of such impacts that citizens in the community are exposed to in daily life and that is most palpable to them. ${ }^{78}$

and policies.

${ }^{75}$ See infra Part IV.B.2.

${ }^{76}$ See Letter from Ann E. Goode, Director, EPA, Office of Civil Rights, to Father Phil Schmitter, Sister Joanne Chiaverini, Co-Directors, St. Francis Prayer Center, and Russell J. Harding, Director, Michigan Department of Environmental Quality, (Oct. 30, 1998), available at http://www.epa.gov/region5/steelcvr.htm (last visited Oct. 5, 2001) (on file with the Harvard Environmental Law Review). See also Luke Cole, "Wrong on the Facts, Wrong on the Law": Civil Rights Advocates Excoriate EPA's Most Recent Title VI Misstep, 29 ENVTL. L. REP. 10,775 (1999).

7 See Cole, supra note 76 at 10,777 (arguing that belief of compliance with air quality standards for ozone was false).

${ }^{78}$ See National advisory Council for Environmental Policy and Technol- 
In some respects, the failure of the administrative process to address the substance of such disparate impact claims should not be surprising. After all, the process and its methodology are designed to inquire into specific quantitative measures of disparities, numbers that may not exist in the form demanded by EPA's analytical method. As a result, without an approach significantly different from its traditional decision-making processes, EPA's Title VI administrative process is unlikely to be satisfactory for environmental justice advocates. ${ }^{79}$

\section{The Limits of Regulation: The Debate About the Market Dynamics Cause of Disparate Hazardous Waste Facility Siting}

As noted previously, the idea of the environment as an interconnected whole has formed the basis for comprehensive approaches to environmental protection. Such approaches have sought to regulate a wide range of environmentally degrading activities, ranging from private individual behavior to commercial and industrial activities. ${ }^{80}$ In doing so, federal environmental laws have sought to adopt a holistic, system-based view of a problem rather than focusing only on particular aspects of it.

Under the environmental regulatory paradigm, the desirability and acceptability of human activities and decisions are judged by their harmful or beneficial impact on the environment. There are no areas of human activity that are automatically or inherently off-limits if judged harmful to the environment. Within this framework, the key question is: Does it tend to harm, directly or indirectly, the environment? If it does, the activity is considered the legitimate subject of government regulation.

In contrast, consider the limitations on discrimination remedies that have arisen out of the Brown paradigm. ${ }^{81}$ Little of the holistic and com-

Ogy, RePort of the Title VI Implementation Advisory CoMmittee: NeXt Steps for EPA, State, and Local Environmental Justice Programs 57-65, 70-75 (Mar. 1, 1999), available at http://www.epa.gov/ocrpage 1/t6faca.htm (last visited Oct. 5, 2001) (on file with the Harvard Environmental Law Review).

${ }^{79}$ The need for an effective EPA administrative process has become more important after Alexander v. Sandoval, 531 U.S. 1049 (2001), which found no private right of action to enforce EPA's Title VI disparate impact regulations.

${ }^{80}$ See, e.g., Pollution Prevention Policy Statement, 54 Fed. Reg. 3845, 3847 (Jan. 26, 1989) ("EPA believes that the development of a comprehensive multi-media pollution prevention policy offers enormous promise for improvements in human health protection and environmental quality."); Pollution Prevention Strategy, 56 Fed. Reg. 7849 (Feb. 26, 1991); RODGERS, supra note 33, at 59-60.

${ }^{81}$ As I noted in the introduction, my argument here is not that no other relevant authoritative case law exists in anti-discrimination law nor that Brown necessarily is on point for all areas of anti-discrimination law. Rather, Brown and its progeny are representative of the limitations on the government's and the courts' power to regulate and redress discrimination. See, e.g., Washington v. Davis, 426 U.S. 229, 240 (1976); Milliken v. Bradley, 418 U.S. 717 (1974). See also Sandoval, 531 U.S. at 1049 (determining that disparate impact regulations promulgated by agencies under Title VI of the Civil Rights Act cannot be enforced directly by private individuals). 
prehensive perspective of environmental regulation is evident in traditional civil rights jurisprudence. ${ }^{82}$ Brown's progeny have limited not only the remedies to discrimination, as the school desegregation cases have shown, but also the reach of civil rights protections themselves by imposing the discriminatory intent requirement.

These contrasts also shed some light on the debate that has haunted empirical studies of the siting of hazardous waste facilities and other waste disposal facilities in minority neighborhoods: What is the cause of the disproportionate presence of hazardous waste disposal facilities in poor and minority communities? Is it due to the racial and socioeconomic characteristics of the community, or is it traceable to other causes? ${ }^{83}$

Environmental justice activists have claimed that such disproportionate waste facility siting is the result of discrimination in site selection. Yet an alternative theory advanced by Vicki Been has pointed to the role of market dynamics. According to market dynamics theory, the explanation for the disparate impacts on racial minority communities is not that waste facilities are intentionally sited in such communities, but rather that racial minority and poor communities form around such facilities.

Thus, a community surrounding a waste facility can acquire its racial minority or poor character either by the facility causing "those who can afford to move to ... leave the neighborhood [or] by making the neighborhood less desirable, ... decreas[ing] the value of the neighborhood's property, [and] making the housing more available to lower income households and less attractive to higher income households." 84 Combined with other forms of housing discrimination elsewhere, the neighborhood may become poorer and acquire a greater racial minority population than before. ${ }^{85}$

The market dynamics theory thus posits that external market forces create the racial and socio-economic character of the neighborhood after the siting of a waste facility; such communities do not pre-exist the siting decisions. This conclusion is significant to environmental justice because, "if the disproportionate distribution of locally undesirable land uses ("LULUs") results from market forces which drive the poor, regardless of their race, to live in neighborhoods that offer cheaper housing

${ }^{82}$ Cf. Milliken, 418 U.S. at 758 (1974) (Douglas, J., dissenting) (unsuccessfully arguing that comprehensive metropolitan solution to school desegregation efforts should be permissible just as "[m]etropolitan treatment of . . . a sewage problem or a water problem, or an energy problem ... would stay well within federal constitutional bounds" and "is commonplace").

${ }^{83}$ The answer to the question of whether such disparities exist seems fairly settled. See Been, supra note 17.

${ }^{84}$ Vicki Been, Locally Undesirable Land Uses in Minority Neighborhoods: Disproportionate Siting or Market Dynamics?, 103 YALE L.J. 1383, 1388-89 (1994).

${ }^{85} I d$. at 1389. 
because they host LULUs, then the fairness of the distribution becomes a question about the fairness of our market economy." 86

In keeping with its controversial assertions, the market dynamics theory has been criticized for conflating normative judgments about the causation of disproportionately distributed hazardous waste facilities with factual inquiries into whether the racial minority make-up of a neighborhood preceded the decision to site a facility or came in its wake. ${ }^{87}$ After all, "if existing racially discriminatory processes in the housing market, for instance, contribute to the distribution of environmental hazards, then it is entirely appropriate to call such outcomes unjust, and even racist." 88

Market dynamics theory and Been's argument that it fundamentally changes the question of racial justice into a question of economic justice also reveal the incompatibilities of the environmental and civil rights paradigms. In her explanations of the significance of market dynamics, Been has been careful to point out the contributions of racial segregation and other forms of discrimination in such dynamics. ${ }^{89}$ However, the clear import of her market dynamics argument is that if it turns the question about the "fairness of the distribution [into] a question about the fairness of our market economy," then race is no longer the relevant issue. ${ }^{90} \mathrm{By}$ implication, such disparate impacts are outside of the problem of environmental racism.

Under Brown and its progeny civil rights doctrines, this is unsurprising. If no specific culpable bad actor with discriminatory intent or a discrete set of discriminatory events can be identified, traditional antidiscrimination analysis provides no remedy. However, that does not mean that there is no discrimination problem. Rather, it is a "simple" case of discriminatory impact, traceable to and presumably connected to larger social issues and problems of discrimination. It is thus outside of the purview of traditional government regulatory responsibility. ${ }^{91}$ The market

${ }^{86} \mathrm{Id}$. at 1391 . Been's most recent national studies appear to indicate that racial minority communities surrounding hazardous waste disposal facilities generally preceded the siting of the facilities in their midst. Others, however, have provided empirical evidence apparently supporting the operation of market dynamics in particular instances. See, e.g., Thomas Lambert \& Christopher Boerner, Environmental Inequity: Economic Causes, Economic Solutions, 14 YALE J. ON REG. 195, 203-12 (1997) (examining waste facility siting in St. Louis, Missouri).

${ }^{87}$ Foster, supra note 3, at 793-98.

${ }^{88}$ Id. at 798; see also Gerald Torres, Introduction: Understanding Environmental Racism, 63 U. Colo. L. Rev. 839, 839 (1992).

${ }^{89}$ Been, supra note 84 , at 1390 .

${ }^{90} \mathrm{Id}$. at 1391. See also David Schoenbrod, Environmental 'Injustice' Is About Politics, Not Racism, WalL ST. J., Feb. 23, 1994, at A21. According to David Schoenbrod, "[a]lthough minority communities have a disproportionate share of environmental problems, research suggests that the cause is not necessarily racial discrimination. Environmental hazards are likely to be placed in any community that either lacks political power or is willing to accept risks because they create jobs or generate taxes."

${ }^{91}$ Washington v. Davis, 426 U.S. 229 (1976). Such thinking in environmental law is, of 
dynamics theory thus implicitly chooses the anti-discrimination paradigm as the limiting principle for understanding environmental justice issues.

However, following this line of reasoning is unsupportable from an environmental perspective. Market dynamics theory assumes that the social phenomena it describes are somehow outside of the legitimate scope of problems that, like the human desires to consume natural resources, ought to be the subject of environmental regulatory action. Yet, if we take seriously the environmentalist's tenet that everything is connected to everything else, how can we do so in a principled fashion?

The environmental regulatory system has not shied away from seeking to change human behavior and social and economic practices on a large scale to protect the environment. Promotion of public transportation to reduce air pollution, imposition of numerous detailed environmental statutory and regulatory requirements to change behavior within industry, and the use of economic incentives and market mechanisms have demonstrated this clearly. The phenomena that are described as market dynamics, to the extent that they contribute to excessive and disparate levels of pollution in some communities, are no different. ${ }^{92}$

The decision to label the phenomena in such a fashion, and thus place them outside of the scope of ordinary government protections, obscures the obligation that environmentalists and regulators might otherwise be under to take such phenomena into account. In essence, the market dynamics perspective makes it that much easier for environmentalists, government regulators, and industry to absolve themselves from responsibility for addressing societal discrimination and social inequities in addressing the causes of environmental problems.

Both the market dynamics debate and EPA's Select Steel decision show the insufficiency of even the traditional civil rights paradigms for

course, not new. The same issue has been raised in the context of the National Environmental Policy Act ("NEPA") and its environmental impact review process. There, courts have sought to distinguish between environmental and other socio-economic impacts that must be included in NEPA analysis. Thus, while socio-economic impacts that are connected to other physical environmental impacts must be included in NEPA analysis, pure socio-economic impacts without a connection to a physical environmental impact need not be.

92 Market dynamics theory as an explanation for disparate siting of LULUs, however, is not the only instance where application of the anti-discrimination regulatory paradigm cuts off traditional environmental concerns for environmental justice claims.

As Heidi Gorovitz Robertson has pointed out, the grandfathering of pollution permits has a significant impact on racial minority communities. Heidi Gorovitz Robertson, If Your Grandfather Could Pollute, So Can You: Environmental "Grandfather Clauses" and Their Role in Environmental Inequity, 45 CATH. U. L. REV. 131 (1995). Here, the failure of regulators to address such sources of pollution aggressively arises because of vested expectations by permit holders. Not unlike in other approaches to discrimination, significant environmental and health impacts on surrounding communities are outweighed by traditional solicitude for property rights. This presents quite a contrast to the forcefulness with which the federal government has approached clean-ups of hazardous waste sites under the Comprehensive Emergency Response and Cleanup Liability Act ("CERCLA"). 
evaluating environmental justice claims. Of course, the more general problems posed by inappropriate regulatory approaches for new and unfamiliar types of claims have not been unique to environmental justice advocates. An analogous story can be told about the structural reform litigation that followed Brown v. Board of Education's mandate to desegregate public schools. ${ }^{93}$ They are the same structural problems that proved the courts and common law principles incapable of addressing modern pollution issues.

It is thus especially ironic that environmental regulators, who have been particularly sophisticated about addressing such types of problems in the environmental context, have failed to heed their own historical experience. By rotely relying on traditional civil rights paradigms without consideration of how of the environmental context changes things, regulators are running the risk of re-introducing concepts and approaches that they themselves abandoned as unworkable in earlier times.

\section{Taking Discrimination and Equity Seriously}

\section{A. Addressing the Tensions Between the Two Paradigms}

Given that the environmental and discrimination paradigms are in significant tension with each other, how ought we address these tensions? At one level, we might simply attempt to change one or the other of the two regulatory systems so as to achieve the regulatory goals that the other paradigm seeks to address. We could accomplish this by utilizing both regulatory approaches when they are not mutually exclusive, as one might be tempted to do with regard to the role of courts and administrative agencies in protecting the environment. ${ }^{94}$ And when the regulatory approaches conflict or neither is satisfactory, we can instead try to design a new system or new regulatory tools that do achieve the goals pursued by the conflicting approaches or at least strike a reasonable balance between them.

However, that would miss a central point of the above discussion. The question of how to address environmental protection and discrimination concerns is not simply a legal or technical regulatory question. The legal and regulatory approaches embodied within environmental and civil rights law and policy are premised not only on technical assess-

${ }^{93}$ In fact, the difficulties that courts encounter in addressing systemic and past discrimination problem with the tools and powers available to them has been well illustrated by Abram Chayes. See Abram Chayes, The Role of the Judge in Public Law Litigation, 89 HARV. L. REV. 1281 (1976).

${ }^{94}$ See, e.g., David Schoenbrod, Protecting the Environment in the Spirit of the Common Law, in The Common Law and the Environment: Rethinking the Statutory Basis for Modern Environmental Law 3 (Roger E. Meiners \& Andrew P. Morriss eds., 2000). 
ments of the problems that are to be solved but also on fundamental value judgments. To the extent that conflicting technical regulatory and legal doctrinal approaches evince fundamental value conflicts, we are forced to make some difficult choices between them. These tensions emphasize that the demands for "environmental justice" implicate issues much more far-reaching than simply "fixing" environmental regulations.

Yet many of the complexities of the problem discussed here resolve into a fundamental value choice. It is a judgment about who the primary beneficiary of the regulatory system ought to be-in environmental law, it is the collective as a whole, while in civil rights law it is racial or other minority groups. This is a choice that drives most of the difference between the regulatory paradigms and without which there would otherwise be no significant theoretical obstacles to reconciling those approaches.

For instance, the focus within environmental regulation on quantifiable considerations does not per se preclude the consideration of intangible values and qualitative factors, even if it does marginalize their importance. In fact, the importance of some intangibles, such as the value of endangered species and other natural resources to future generations as a matter of aesthetics and ethical concern, has not escaped policy-makers and environmentalists. ${ }^{95}$ Thus, the lack of familiarity of environmental policy-makers with anti-discrimination values should not present an insurmountable impediment. To the extent that incorporation of civil rights values would lead to greater sensitivity of regulators to intangible values more generally, it would arguably strengthen and improve environmental regulation as a whole.

The related structural question is more difficult. Assuming that racial minority protections should be taken seriously, do environmental regulators possess the institutional competence to consider and implement civil rights values and norms? Can and should bureaucrats be involved in administering sensitive issues such as racial equality and nondiscrimination? The continued importance of common law adjudication in civil rights protection seems to suggest the contrary.

Regulators may be familiar with technical assessments, scientific methodology, and consensus decision-making. But that does not prepare them for social problems that require a sense of the history of race relations, an appreciation of the sociology and psychology of inter-personal and institutional racial dynamics, and a sensitivity to the law and politics of the counter-majoritarian protection needs of minorities.

As a technical/scientific administrative body subject to the control of politically elected officials, an expert agency's structure is well-suited to address issues that command a significant amount of political consensus

${ }^{95}$ See, e.g., Endangered Species Act of 1973, 16 U.S.C. $\$ \$ 1531-1544$ (1994); National Historic Preservation Act, 16 U.S.C. $\$ \$ 470$ to $470 x-6$ (1994). See also LeOPOLD, supra note 39. 
and that do not require it to make delicate social value judgments. In contrast, choosing among competing and legitimate political and social choices is not among its strengths.

That does not absolve EPA, or other administrative agencies for that matter, of responsibility for addressing the concerns of racial minorities and other disenfranchised groups. And in the end, concerns about the dangers of bureaucratization might not be as significant as they appear. Government agencies are already involved in many areas of policymaking and regulation that implicate important civil rights and civil liberty issues, ranging from public health to education to social services. Furthermore, the experience with race-conscious affirmative action programs are another set of experiences that can be drawn upon to appropriately shape government involvement.

More importantly, the greatest risk to the interests of minorities and the poor that arises from administrative process comes from the abovedescribed characteristics of administrative processes themselves, rather than the labeling of a process as administrative or judicial. Thus, to the extent that the characteristics of the process used to deal with minority interests are changed to address these risks, such as through the use of administrative adjudicative processes, the goals and values of the environmental justice movement can be significantly advanced. ${ }^{96}$

The place of the states within the environmental regulatory and civil rights protection system also presents tricky issues. After all, their contrasting historical role in promoting discrimination and protecting the environment is reflected in national concerns about the lesser solicitude of sub-national and local government entities to the rights of racial minorities, but federal confidence in their ability to make important contributions to protecting the environment. Reconciling their different relationships to the federal government seems thus like an attempt to marry suspicion of states under civil rights laws with trust under the environmental laws-a seemingly schizophrenic proposition.

In the end, the relationship between states and the federal government hinges on resolving the question of whose interests are of primary concern to the regulatory system-the larger collective's or minority groups.' As noted above, the dichotomy is not just a historical artifact rooted in the contrasting history of environmental regulation and civil rights law. ${ }^{97}$ It is also reflective of deeper concerns about institutional competencies and concerns related to minorities.

${ }^{96}$ While I cannot engage in a deeper analysis of what such a process would have to look like, at a minimum, it would need to be insulated from ordinary political and agency pressures and adequately immersed in and cognizant of the concerns of civil rights law in order to be effective. Some re-involvement of the courts may also be necessary as a means of review of such mechanisms.

${ }^{97}$ Even if the dichotomy were only an historical artifact, it would still raise some important practical considerations regarding institutional inertia to resist change. 
However, while a federal agency genuinely concerned with minority communities cannot provide local governments with a significant and substantive role in a minority protection scheme, that does not mean that state and local governments must be excluded from other aspects of environmental regulation. In any case, the regulatory activities of states and local governments must be supervised and critically examined when allegations of discrimination or inequity are raised.

Finally, the question of what the appropriate limits to regulation ought to be again appears to raise important choices. Are there areas where regulation is inherently inappropriate because of important competing values? Notwithstanding assertions of property rights and the restrictions that the takings clause has imposed, the answer to that question must largely be "no" for environmental regulation. The opposite has been true for anti-discrimination, where values such as free speech as well as the rights of non-minorities have resulted in significant limitations to the reach of anti-discrimination laws and the effective scope of remedial measures.

In many respects, these aspects of the regulatory paradigms would appear to be the easiest to combine with regard to the achievement of the goals and ideals of the environmental justice movement. However, such a combination requires a choice that is different from that made by regulators in the past, lest one fall into the trap of choosing the antidiscrimination paradigm, as market dynamics theory does. It requires environmental regulators to take the notion of an interconnected environment, including its linkage to human society and values, and the goal of comprehensive regulation seriously. Rather than falling into orthodox notions that harm resulting from actions without intent is not truly a harm, regulators must look to the actual effects on the poor and communities of color and use such impacts as the yardsticks for action.

While there are no easy solutions, most of the differences between the paradigms would be resolvable if the political will to do so were to exist. The only difference that cannot be resolved here is the question of whose interests the regulatory system should put first: the collective majority or minority groups.

\section{B. The Place of Race and Equity Within Environmental Governance}

Given the fundamental value choice that one must make with regard to the place of minority concerns within the environmental regulatory system, how should one choose? Should concerns about especially vulnerable groups be elevated to the importance demanded by environmental justice activists? This question raises important questions about the purpose of environmental governance and the role of social justice considerations within it. 
In light of the important environmental degradation problems that the United States, and for that matter the world, faces, it is understandable why traditional environmentalism might desire to put the common good before the "special" interests of any particular group, including racial minority groups or the poor. If we are unable to solve globally pressing problems such as ozone depletion, climate change, or the loss of biodiversity, we might not have an environment, or a planet, left that is hospitable to human society. Without an effective and expeditious solution to such larger problems, there will be nothing left for racial minorities or the poor to live in, or for that matter anyone else.

However, as compelling as such an argument might be, it proves too much. It is a justification that has been heard all too often by racial minorities and other disenfranchised groups-sacrifice of their interests in the name of the common good. Too frequently, it has served as a pretext for the exploitation or scape-goating of racial minorities. In addition, this justification has been heard before, whether it was with regard to the legality of slavery in $1787^{98}$ or in 1945 with regard to the internment of American citizens of Japanese ancestry. ${ }^{99}$

The fact is that ignoring or neglecting the interests of the disenfranchised in order to achieve an overriding common good is altogether too easy an excuse. Traditional approaches to regulation, in particular environmental regulation, have a tendency to use the good of the larger community as an excuse to take measures that are easy but that also impose significant burdens on minorities, instead of searching for and pursuing options that are more difficult yet more equitable. After all, protecting minority interests in the political process is never easy, precisely because they run contrary to those of the majority. To sacrifice the interests of the minority in pursuit of the greater good is inevitably a means of avoiding the true, and more difficult, question that a particular problem presents. For government regulators and officials, doing so evades their responsibility not only to minorities, but also to the larger community that believes in the ideals of equality.

Of course, I am not arguing that we should always pick the path that will place the interests of minorities over those of the majority. I am simply arguing that such a decision should be among the choices considered in situations where environmental and civil rights issues intersect.

In fact, the bottom line is that most of the environmental justice issues that have arisen in the past have not raised those types of difficult

${ }^{98}$ See Derrick Bell, Jr., The Real Status of Blacks Today: The Chronicle of the Constitutional Contradiction, in AND We aRe Not SAVED: THE Elusive QUeST for Racial JusTiCE 26, 26-42 (1987) (arguing that a principled position against slavery in the constitutional convention was sacrificed in order to obtain the support of the slave-holding South for the Constitution); see also PEREA ET AL., supra note 27, at 103-05 (illustrating analogous arguments about slavery used in 1787 and the Civil War).

99 See generally PETER IRONS, JUSTICE AT WAR (1983). 
questions-far from it. To contend, for instance, that environmental justice claims usually force poor and minority communities to make a choice between jobs and the environment misunderstands what the fundamental problem is that they face. The-jobs versus environment-dilemma arises when a community faces the prospect of an industrial facility that promises to create new jobs and may stimulate the local economy, while the facility will also impose health risks as well as lower the quality of the environment due to noise, odor, traffic, and the like. Even if the realities of life are hard, conceiving of such problems as simply a choice of jobs versus the environment evidences a profound lack of understanding of the problem faced by environmental justice communities. In a sense, it is a false choice. It obscures the underlying reality that minority communities and the poor have generally not been treated fairly in the past.

What environmental justice communities demand and deserve are not simply options that pretend that the past has not happened and that seek to lock their subordinated and disadvantaged status into place. Rather, they deserve a fair share of public goods, including a healthy environment and the benefits of economic development, to the same extent that it is afforded to wealthy non-minority communities. That is the underlying premise of the call for equality.

In times when the administrative state and its regulatory agencies govern many aspects of life and channel behavior in ways that seek to promote the public interest, the equal protection doctrine's credo "do no harm,"100 or, more bluntly put, "do not intentionally discriminate,"101 seems entirely insufficient and dated. Today, the government is engaged in myriad affirmative programs to promote and to make available public goods. A continued failure by government to take more active steps to remedy the harms of discriminatory effects within its programs resulting from more amorphous forms of current-day societal discrimination or past discrimination is as harmful as the active discrimination that was the mark of prejudice and bigotry during the heyday of racism and segregation.

\section{CONCLUSION}

At its core, environmental justice is an issue that ought to be of concern not only to the kind-hearted and socially conscious. Its concerns go to the heart of democratic governance and what it means to live in a just society. As a result, environmental justice concerns cannot be considered only in the narrow context of environmental regulation and its goals, as the attempts to fit it within the existing environmental regulatory system 
have sought to do. And its goals, although most visibly identified as that of fighting environmental racism, do not stop with the eradication of what the U.S. Supreme Court has legally defined as intentional discrimination-actions intended to disadvantage or harm members of racial minority groups based on a racial animus. Rather, environmental justice challenges environmental regulators to look up from their desks and environmentalists to come out of the wilderness and to understand how environmental protection efforts are related to broader social agendas. A failure to live up to the challenge will not only leave environmentalism weaker as a compelling ideal, but also poorer as a moral force. 